\title{
Uncertainties, Protectionism and Slowdown in Global Trade
}

\author{
Prof. Dr. Ercan Uygur (Turkish Economic Association, Turkey)
}

\begin{abstract}
The United States announced plans to impose tariffs and quotas on her imports of certain commodities, notably iron, steel and aluminum, and on imports from certain countries, including those from China, in early 2018. These and counter announcements has been considered as the start of global trade wars.

Even before that, there has been a significant slowdown in the growth of world trade in recent years. In the three decades before 2011, annual world trade recorded a growth of about $6 \%$. This was twice as high as world GDP growth, implying an income (GDP) elasticity of trade at around 2. Between $2011-2016$, the income elasticity of trade has fallen to below 1 , on average.

While the recent poor performance of global trade has been attributed to these structural and cyclical factors, this paper argues that the rise in both price uncertainty, demand uncertainty and policy uncertainty have and will have a significant effect on trade growth. Price uncertainty is reflected in fluctuations in real exchange rates, commodity prices and manufacturing prices. Demand uncertainty, on the other hand, is reflected by growth variability in time and among countries. Policy uncertainty can be traced in protectionist measures.
\end{abstract}

